\title{
WMD Transformations: When did an RPG become a WMD?
}

\author{
Binoy Kampmark
}

\begin{abstract}
The Iraqi regime has used weapons of mass destruction. They not only had weapons of mass destruction, they used weapons of mass destruction. They used weapons of mass destruction in other countries, they have used weapons of mass destruction on their own people. That's why I say Iraq is a threat, a real threat.
\end{abstract}

- George W. Bush, Address at Ford Hood, Texas, Jan 3, 2003

The transformation of the term Weapons of Mass Destruction (WMD) from its specifically destructive characteristics to multiple, surprising variations in its socio-legal and political sense has been dramatic. This essay examines the absurd play of language inherent in the use of the term WMD, discussing the way weapons of apocalyptic terror became weapons of domestic innocuousness. From its appearance in the 1930s as a term of use, to its dissimulative abuse by the Bush administration leading up to the invasion of Iraq in 2003, WMD became a matter of fantasy, nightmare, comic relief and military justification. Its absurd finale has come in the form of the ultimate mockery - the use of a Rocket Propelled Grenade or pressure cookers filled with nails.

\section{WMD as Terminology}

In 1873, Friedrich Nietzsche suggested that figures of speech, "after long use, seem firm, canonical and obligatory to a people". Truth, suggested Nietzsche in a radical reappraisal of its meaning, is, "A mobile army of metaphors, metonyms, and anthropomorphisms - in short, a sum of human relations which have been enhanced, transposed, and embellished poetically and rhetorically, and which after long use seem firm, canonical and obligatory to a people; truths are illusions about which one has forgotten that this is what they are; metaphors which are worn out and without sensuous power; coins which have lost their picture and now matter only as metal, no longer as coins" (1954: 46-7).

Lotfi Zadeh, in an illuminating study of systems analysis, argues that human understanding is generally founded on "labels of fuzzy sets... classes of objects in which the transition from membership to non-membership is gradual rather than abrupt" (1973). Human reasoning, to that end, comprises a "logic of fuzzy truths, fuzzy connectives, and fuzzy rules of inference." As a system increases in complexity, the means of making judgments that are "precise yet significant" on its operation "diminishes until a threshold is reached beyond which precision and significance... become almost mutually exclusive characteristics" (1973: 28-44).

Weapons of Mass Destruction (WMD), one of the twenty-first century's more famous abbreviations as WMD, became a term of conflation, used repeatedly, thereby obscuring "the distinctions among chemical, biological and nuclear weapons" (Oren and Solomon 2006: 1). Precision and significance became, to use the terms of Zadeh, mutually exclusive. Whether it is the "mobile army" of various lexical forms suggested by Nietzsche, or a matter of "fuzzy truths" and "connectives" inherent in a system of reasoning, the WMD fixation has taken states to war, resulted in absurd domestic adjustments to laws, notably those in the United States, and seen a satirising of the term. The current legislation in the United States reflects this expansion. 


\section{Learning to Love WMD}

The term WMD has a curious biography. An address in 1937 by the then Archbishop of Canterbury Cosmo Gordon Lang is cited as one source where the term first appears. His subject of reference were wars taking place in China and Spain, where technological developments were becoming increasingly murderous to civilian populations. "Who can think without horror of what another widespread war would mean, waged as it would be with all the new weapons of mass destruction" (Cullinane Apr 26 2013). The context there seemed clear - the bleak promise of total war, the massacre of civilians by industrialised forms of mass killing that obliterated distinctions between combatant and non-combatant. The Basque town of Guernica had been levelled by German bombers, prompting George Steer of The Times (Apr 27, 1937) to describe the range of terror tactics employed to subdue then destroy the populace.

The United Nations deliberated over the use of such a term in the context of disarmament policy in 1948, coming up with a definition that included "atomic explosive weapons, radioactive material weapons, lethal chemical and biological weapons, and any weapons developed in the future which may have characteristics comparable in destructive effect to those of the atomic bomb or other weapons mentioned above" (Reichart and Carus 2012). Two years prior to that, it passed a resolution - its' first - establishing a committee to draft proposals relevant to various topics, including those concerned with "the elimination from national armaments of atomic weapons and of all other major weapons adaptable to mass destruction" (UN, A/Res/1(1) 1946).

Rendering the term WMD benign and indistinct has been a gradual outcome of the military industrial complex that grew up during the Cold War. Horror can be dealt with by minimising the threat - duck and cover, get under a desk, hide in ineffectual shelters and watching such propaganda products as Bert the Turtle whose shell will shield against extraordinarily destructive forces. A nuclear attack might well take place, but you may well still live. "Megadeath intellectuals" made apocalypse and Armageddon the necessary staples of the military industrial establishment.[1] Historiography on the subject of the first genuine WMD - the atomic bomb - shows that, far from being kept singular and spectacular as a weapon of destructive force, it would be normalised and rendered, in time, a feature of the tactical framework of the armed forces. Little wonder then that a redefinition was taking place from the other end - making domestic, seemingly harmless utensils of daily weapons WMDs.

The bomb, in other words, had to be loved, an instrument of power both useful and indispensable. As Lt. General James Gavin would write in 1958, "Nuclear weapons will become conventional for several reasons, among them cost, effectiveness against enemy weapons, and ease of handling" (1958: 265). The tag of being "conventional" and being treated as any other weapon, was deemed an inevitability by such planners as Secretary of State John Foster Dulles (NSC May 27 1957; Tannenwald 2005: 5). Certainly, the normalisation of such weapons finds form in Stanley Kubrick's film Dr. Strangelove or: How I Learned to Stop Worrying and Love the Bomb (1964), which only alludes to the cataclysm around the corner. The point, as the conclusion of the film suggests to the voice of Vera Lynn, is that "we will meet again" - the WMDs employed are not going to wipe out the entire human race after all. This is all part of the order of living.

There is another sociological phenomenon in the military complex worth noting even as the nuclear or WMD option is sliding into the background as standard fare for some states. During the Obama administration, there has been a conspicuous move to increase the significance of spectacular conventional weapons that are, for all intents and purposes, unconventionally powerful in their firepower. The initiation of a "global strike capability" that is growing in popularity in the White House and the Pentagon has been deemed to be so threatening that it might encourage smaller, less capable states to use a nuclear option (Grossman Aug 22 2012). The reliance on robotic and drone warfare is very much of the same ilk.

\section{Fragmentation: WMD and Non-state Actors}

The use of WMD as an expression is casual, presumed, an umbrella for a series of terms, has become common place. That said, a fundamental contradiction developed in the course of WMD discourses. Only some states were entitled to have them. Others, depending on the nature of their regime, are deemed incapable of holding such weapons in their inventory. The same logic has applied to non-state actors, organisations deemed inappropriate as recipients of WMD material. An important feature of this transformation has been the deconstruction of the state in favour of non-state actors with a magnified capability of doing harm. The "non-state" actor has become 
the terrifying imaginary in the planning of officials keen to secure the homeland against the deployment of WMDs.

The U.S. Congress's National Defence Panel group, comprising retired generals and civilian experts, released a report in December 1997 extending the scope of threats to the United States, comprising not merely nuclear attack but WMD, terrorism, information warfare, ballistic and cruise missiles and other "transnational threats". The Defence Science Board also felt that, "The technology of today, and that which is emerging, allows a small number of people to threaten others with consequences heretofore achievable only by nation states." The Board added a note of greater urgency, suggesting that "the likelihood and consequences of attacks from transnational threats can be as serious, if not more serious, than those of a major military conflict" (quoted in Cato Institute 2011: 529).

The entire debate on WMDs is characterised by one running argument: only some should be allowed to possess them. There are monopolies of violence, though the contradictions arise in what geographical and urban spaces these take place in. Those that seek to attain them - countries that are not legitimately accepted by the international community; individuals who are regarded as formally "terrorist" organisations - are prevented from acquiring them.

The fragmentation of the state-WMD nexus was considered in an essay by George Orwell for the Tribune after the conclusion of World War II. He was primarily concerned with what the atomic bomb had done to interstate and human relations. Having such terrifying, obliterating power was dangerous if it was confined to states - a cheaper manufacture of such weapons would, far from making the world less safe, enhance its security by democratising the use of mass lethality. Such a view has been developed by such international relations theorists as Kenneth Waltz (1981) - an even distribution of nuclear weapons would make the world more, not less, stable. Having the means to kill the human race with such ease might be its own deterrent from use. Much of this hinged on how expensive the manufacture of the atomic bomb would be. "The atomic bomb," wrote Orwell, "may complete the process by robbing the exploited classes and peoples of all power to revolt, and at the same time putting the possessors of the bomb on a basis of equality. Unable to conquer one another they are likely to continue ruling the world between them, and it is difficult to see how the balance can be upset except by slow and unpredictable demographic changes" (Orwell [Apr Oct 19 1945]1968: 8-10).

Such violence, in short, cannot be democratised, if one is to follow the line of reasoning that only the good may hold the bad. The democratisation of such lethal means is precisely what bothers such figures as Google's Eric Schmidt. "I'm not going to pass judgment on whether armies should exist, but I would prefer not to spread and democratise the ability to fight war to every single human being” (Robertson Apr 13 2013). In February 2013, the Preserving American Privacy Act (PAPA) was introduced into the house designed to limit the uses of drone technology, another extension of such logic.

The United Nations Security Council resolution of April 1991 regarding Iraq's biological, chemical, and nuclear weapons programs provided the clear international example of how certain weapons had to be surrendered and destroyed by a regime. In so doing, it paved the way for what would be the ultimate mockery once that regime did comply. Security Council Resolution 687(c) made the claim that Iraq should "unconditionally accept, under international supervision, the destruction, removal or rendering harmless of its weapons of mass destruction, ballistic missiles with a range of over 150 kilometres, and related production facilities equipment.”

There would also be a system of ongoing monitoring and verification put in place ensuring Iraqi compliance with the measure. Overall, such language reflects an illusion of singularity - that such weapons are only spectacularly destructive in the presence of the "wrong" people. In the appropriate hands, they are but ordinary extensions of state power, entirely legitimate provided they are controlled. To that end, WMD as a term transforms just as it is being transformed.

\section{Simulacral WMD}

A further linguistic and conceptual fragmentation took place during the Iraq conflict which revealed how the term WMD was an imperial monarch with no clothes, a symbolic echo of an order of a threat that did not exist. The term WMD became an illusion, an absence treated as a simulated presence. It assumed simulacral properties. The weapons were not there, but had to be there for the sake of legitimising the unauthorised invasion of a sovereign state in 2003. The U.S. National Intelligence Estimate (NIE), Iraq's Continuing Programs for Weapons of Mass Destruction (2002) claimed that Iraq was still pursuing its weapons of mass destruction program, that it had reconstituted its nuclear weapons program and would be able to assemble a device by the end of the decade; that it possessed the facilities to 
produce biological warfare (BW) agents; that it had renewed its production of chemical weapons and had 500 metric tons worth of stockpiles; and that it was developing UAVs to deliver BW agents (Commission on the Intelligence Capabilities of the United States Regarding Weapons of Mass Destruction Mar 31 2005: 45).

U.S. Secretary of Defence Donald Rumsfeld ingeniously, if unwittingly, developed the post-modern fantasy of military absences that are still present realities - the absence of any genuine WMDs - in his infamous observation about "known knowns", "known unknowns" and "unknown unknowns" (Rumsfeld Feb 12 2002; Jun 6, 2002). This was a form of abductive reasoning gone mad, a "hunch" without much basis despite being justified as such.[2] "What he forgot to add," quipped the Slovenian philosopher Slavoj Žižek, "was the crucial fourth term: 'unknown knowns', things we don't know that we know - which is precisely the Freudian unconscious." It is precisely in unearthing the "unknown knowns" that the intellectual performs a service, the "disavowed beliefs, suppositions and obscene practices we pretend not to know about" (Žižek Feb 19 2005).

Furthermore, it did not matter that the weapons were never found. Having been dislocated from any direct, verifiable meaning or existence, the very term WMD was liberated of any concrete reference point. Even as former Vice President Dick Cheney was leaving office, he would claim with steadfast certainty that, "What they found was that Saddam Hussein still had the capability to produce weapons of mass destruction. He had the technology, he had the people, he had the basic feed stock" (Ritter Dec 16 2008). It did not matter that the capabilities of dual-use had been degraded by economic sanctions. The fantasy was what sustained the mission.

\section{WMDs: Uses Both Popular and Domestic}

The dual-image Cheney promoted during and after his period in the Bush administration regarding innocent uses of material that might become weapons-grade has a few implications. While the ultimate weapon - the nuclear option - might be normalised, innocuous options such as pressure cookers might well be transformed into lethal weapons and rendered abnormal. "Feed stock" can rapidly be converted into deadly chemicals for use against civilians, even if what was found in Iraq were mere precursor chemicals that could not be used for the manufacture of sarin, tabun or VX chemical nerve agents (Ritter Dec 16 2008). The cultural implication here is that a domestic, civilian use of a particular device (cooking, cleaning, drinking) can rapidly become a WMD. This has been brilliantly demonstrated by several comic sketches during and after the Cold War, where the ordinary use of an object can rapidly become deadly via symbolic representation.

The domestic could well apply to the industrial - and the quip during the radio comedy series Hancock's Half Hour in 1955 is indicative of that very fact. In a skit titled "The Chef That Died of Shame", the comedian Tony Hancock discusses a UN delegate's views that a particular chef's dumplings be added to a list of "Banned Weapons of Mass Destruction." Here, cookery elides with weaponry - a chef's product becomes as lethal as a weapon of mass lethality, the chef as scientist and potential killer. Or perhaps one can see it the other way - WMDs can assume the forms of cuisine made or manufactured by a humble cook, the banal scene that is vested with symbolic destructive force. But such humour has a habit of replicating, as Da Ali G Show demonstrates strikingly when the hip hop journalist Ali G (Sacha Baron Cohen), in the episode Rekognize, refers to WMDs in error as BLTs (bacon, lettuce and tomato sandwiches) - innocuous food again can assume gigantic proportions of terror, and the term itself has little meaning other than a poorly described sandwich.

In conversation with Republican politician and advisor Pat Buchanan, Ali G poses the vital question. "Does you think that Saddam ever was able to make these weapons of mass destruction or whatever, or as they is called, BLTs?" (Liberman Aug 4 2004). Buchanan embraces the malapropism without batting an eyelid, for here, the terms are interchangeable, be they ordinary sandwiches or actual weapons of mass lethality. The benign is credibly lethal; the lethal credibly benign. "Yes. At one time, he was using BLTs on the Kurds in the north. If he had anthrax, if he had mustard gas..." Ali G poses the next question: what if Hussein had just had plain BLTs without mustard. "Would you have been able to go in there then?" "No," comes the answer from an emphatic Buchanan (Liberman Aug 4 2004).

From coming in the form of deadly food, WMDs have also become caricatures and absurdities in popular culture, the brunt of fun for rapper Xzibit, whose album Weapons of Mass Destruction (2004) features a car called a WMD in the song Pimp My Ride. WMDs are totally decontextualised, the framework of reference removed and ultimately replaced by a symbolism of ordinary use. WMDs might be sentiments; they might be breasts for an 
advertising campaign in which they are Weapons of Mass Distraction; they might form the subject of a refund for a travel to Cyprus that ceases to be safe because Saddam Hussein might be able to deploy weapons in 45 minutes. [3]

The advertisement campaign by the budget airline company EasyJet in 2003 constituted a provocative attempt to confront the multifaceted term WMD had become. There, the bikini-clad breasts of a model with the tag "Discover Weapons of Mass Distraction" was deemed irreverent and amusing. But 186 complaints were reported in Britain, some of which cited the trivialisation of the war on Iraq as a primary course of concern. The British Advertising Standards Authority was not on their side, finding that the advertisement had been humorous and unlikely to cause offence. (Billings Jul 30, 2003). “The authority considered that, although the phrase 'weapons of mass destruction' was likely to be seen to refer to recent events in Iraq, the advertisement did not trivialise the deaths, injuries or plight of those involved or affected by the conflict." The reference had been merely "distasteful" (Cozens Jul 302003 ).

The reduction of WMDs to a satirical context, the insinuation that the potency of such weapons had been "sexed up" in the vital dossier that was used, gave further play to the idea that such weapons are manageable but lethal. It is also the fiction that a person who is about to perform sexually is bound to merely be talking through his hat. This enables various constructions of the term to come into play. As Mark Thomas pondered in The New Statesman, bio-weapons may well have been 'in a flat-pack, and that's why they were never assembled in time. As the Americans and Brits invaded, he [Hussein] had the instructions spread all over the palace living room floor, frantically muttering that 'they never look like they do in the picture"' (2003: 11).

The truth is that WMD as a term was itself a mockery, possessing within it its own undermining, it own fastasmic realisations and reconstitutions. It was the object of fun for Google, whose search engine parodied the term WMD when visitors would type in the term and search, only to have the message "404 Not Found" message.

\section{| Legal Extensions}

WMDs have been effectively de-contextualised, their meaning broadened and encompassing. For that reason, the situation where an RPG (Rocket Propelled Grenade) might be deemed a WMD is not as illogical as it might, on first appearance, seem. They are found in the hands of U.S. veterans fighting as foreign soldiers in conflicts, thereby bringing into play the provisions that inculpate the use of WMDs under the U.S. Criminal Code. Few mention the paradox that the entire nation is effectively awash with WMDs by that definition. Was 20-year old Adam Lanza, perpetrator behind the Sandy Hook Elementary killings in December 2012, using such a weapon in deploying a Bushmaster XM 15-E2S rifle?

The drafting of U.S. laws on the subject of WMD became more adventurous and less logical with the passage of provisions that effectively made assault weapons and hand guns WMDs. The relevant expansive section is s. 921, explaining what a "destructive device" can be, including bombs, grenades, and rockets having a propellant charge of more than four ounces (18 U.S.C. $\left.\int 921\right)$. When read in the context of s 2332(a) - Use of weapons of mass destruction - the scope of application is enormous (18 U.S.C. \2332(a)).

As Spencer Ackerman claims, writing in Wired (Mar 29, 2013), "U.S. law isn't particularly diligent about differentiating dangerous weapons from apocalyptic ones." W. Seth Carus of the Centre for the Study of Weapons of Mass Destruction has also commented on the evolution of the term in an occasional paper (No. 8, Jan 2012), noting that "high explosives" found its way into the definition over time. Khalid Ali-M Aldawsari was sentenced in 2012 to life imprisonment for attempting to use a WMD. He had, according to the Departmental release, purchased "chemicals and equipment necessary to make an improvised explosive device (IED) and his research of potential U.S. targets" (U.S. Department of Justice Nov 13, 2012).

Two seemingly absurd applications of the legislation have taken place this year, the first being the case of Eric Harroun, where special Federal Bureau of Investigation agent Paul Hinginbotham decided to charge an American citizen under the provision for using a "weapon of mass destruction". Harroun, a veteran of the U.S. Army, was merely using a Rocket Propelled Grenade in the course of his engagements with the forces of Bashir al-Assad in Syria. Reichart and Carus identify more than 50 instances where WMD has been defined. The authors also observe that the U.S. Criminal Code's reference to high explosives as also falling within the term was "inconsistent with most national guidance and with the usage preferred by the State Department and the international community". In having such a definition, virtually every crime could be prosecuted under the definition. In other words, the distinction regarding WMD was "fuzzy" in a different way than it had been in the case of Iraq. In the latter, it was darkly comic, 
deceptive, non-existent but still a vital factor of policy - the WMD that won't get you because it won't be found but must be treated as a genuine threat. In the former, the weapons exist, but are exaggerated in terms of destructive potential.

Higginbotham explained in his affidavit that, among his various duties was the requirement to "enforce various laws, to include those that involve acts of terrorism by U.S. citizens and involving designated foreign terrorist organisations" (United States of America v Eric Harroun Affidavit, 1). This was of lesser interest than the specific provisions of the U.S. code he sought to rely on. Specifically, the affidavit was filed in support of a criminal charge that Harroun had conspired to "use a weapon of mass destruction outside of the United States, in violation of 18 U.S.C. $\int 2332 \mathrm{a}(\mathrm{b})$." 'The relevant section covers conspiracy to use a weapon of mass destruction outside of the United States.

The sticking point here was also his involvement with a designated terrorist organisation, the al-Nusra front. Purported evidence taken from YouTube and Facebook accounts was also described, including one post with an accompanying video featuring "Downed a Syrian Helicopter then Looted all Intel and Weapons!" Photos featuring the accused holding or possessing an RPG "and other weaponry" were also noted (United States v Harroun Affidavit 3). Once he had finished his fighting in Syria, Harroun promised that he would travel to Palestinian "because of Israeli atrocities there."

Jurist Robert Chesney's views on the subject show an unconscious acceptance, a non-reflexive position on juridical reasoning on the subject. The term WMD has no relevance other than to punish all inappropriate uses of weaponry that might fall within the definition. What mattered was the government's unwillingness in feeding the apocalyptic imagery suggested by a "narrow" definition of WMD. "At the bottom, it is simply a statute that makes it a felony to set off bombs in public places, which certainly applies in this case. Unless the government were trying to take advantage of the WMD language to try to convince the public that this defendant was using a WMD in the usual narrow and scary sense of that phrase, there's really no harm in the situation in my view" (quoted in Cullinane Apr 26 2013).

Alan Dershowitz of Harvard Law School was surprised with the use of the WMD definition, suggesting that the indictment should have been best made under the federal terrorism statute. "Instead they charged him under a very rarely used statute involving explosion of weapons of mass destruction that result in the death of an individual" (quoted in Cullinane Apr 26 2013). The point with the charge, suggested Dershowitz, was that the prosecution would not have to show an intention to carry out a politically or religiously motivated crime.

The second instance of how the WMD provision has been deployed this year involved the bombings in Boston, where the surviving suspect was charged for devices used at the Boston Marathon on April 15. Here, a device's conventional domestic application became became lethal, and the comic culinary reference of Tony Hancock becomes a serious application of a statute to a "terrorist" act. Suspect Dzhokhar Tsarnaev, like Harroun, found himself facing charges under the WMD article of the US criminal code including "use of a weapon of mass destruction" and "malicious destruction of property resulting in death." The weapons in question were improvised pressure cookers. The Justice Department complaint itself claimed that both pressure cookers were of the same brand, contained metallic BBs and nails, many of which were contained in an adhesive material. They also "contained a green-coloured hobby fuse" (Apr 15, 2013). The way the designation was used did not escape the attention of some commentators. "Iraq dictator Saddam Hussein didn't have weapons of mass destructions, but two young Boston bombers did?" (Mucha, Apr 15, 2013).

\section{Reflections on WMD}

The unreality of the term WMD, connoting mendacity, known unknowns, and forgeries - the false link with Niger and uranium being the most spectacular case in point prior to the invasion of Iraq in 2003 - has rendered the term hollow, or to be more precise, an echo, a suggestion of what might be but is not. In so having its meaning suspended, the term has assumed a lexical flexibility. The nature of "conventional weapons" has also been a casualty of the U.S. policy on what constitutes a WMD - the conventional means of killing and the unconventional method of destruction have no clear utility in current military strategy. The term can, quite literally, be used for anything. It can denote any degree of harm or induce any degree of fear. It can even be the plaything of youngsters, "a bunch of lads from Illford frantically trying to finish their work after a lunchtime session on a Friday” (2003: 11). 
The evolution of the term WMD has not merely become inconsistent and fuzzy, to recall Zadeh's term, but mutually exclusive to its own definitions and applications. An RPG has equal standing to a nuclear weapon or nerve gas. A pressure cooker keeps company with siren gas and other toxins. Food can kill. The term WMD is simultaneously absurd and significant. It exists in some forms, becomes invisible in others. In all cases, its effects are genuine, shaking makers of policy and troubling law makers. In all cases, its use has become absurd.

Dr. Binoy Kampmark was a Commonwealth Scholar at Selwyn College, Cambridge. He lectures in the School of Global, Social and Urban Studies at RMIT University, Melbourne. Email: bkampmark@gmail.com

\section{Endnotes}

1. Marcus Raskin, “The Megadeath Intellectuals," New York Review of Books, Nov 14, 1963, 6-7; Murray N. Rothbard, "George Orwell and the Cold War: A Reconsideration," in Robert Mulvihill, ed., Reflections on America, 1984: An Orwell Symposium (Athens and London: University of Georgia Press, 1986), http:// www.lewrockwell.com/rothbard/rothbard32.html_ $\mathrm{ftn} 3$

2. For abductive reasoning, see Charles Peirce discussing artists and how they arrive at choices: Collected Papers of Charles Sanders Peirce (Cambridge, MA: Harvard University Press, 1958).

3. Faithless, in the album No Roots (2004), with the single "Mass Destruction" featuring greed and racism as "weapons of mass destruction"; EasyJet Advertisement featuring bikini clad breasts as "Weapons of Mass Distraction": Claret, Susan Townsend, Adrian Mole and the Weapons of Mass Destruction (2004).

\section{References}

Billings, Claire. "Easyjet 'weapons of mass distraction' ad evades censure.” Brandrepublic.com, Jul 30. http://www. brandrepublic.com/news/186573/. Accessed Jul 30, 2013.

Cato Institute. 2001. Cato Handbook for Congress. http:// www.cato.org/sites/cato.org/files/serials/files/cato-handbookpolicymakers/2001/9/hb107-50.pdf. Accessed Jul 18, 2013.

Commission on the Intelligence Capabilities of the United States Regarding Weapons of Mass Destruction. 2005. Report to the President of the United States. Mar 31. (Summary of the classified report to the President, Mar 31, 2005).

Cozens, Claire. 2003. "Easyjet ads escape censure," The Guardian, Jul 30. http://www.guardian.co.uk/media/2003/jul/30/ advertising.travelnews. Accessed June 21, 2013.
Cullinane, Susannah. 2013. "WMD: A-bombs to Pressure Cookers.” CNN, Apr 26, http://edition.cnn. com/2013/04/26/world/weapons-of-mass-destructionexplainer. Accessed June 30, 2013.

Gavin, James M. 1958. War and Peace in the Space Age. New York: Harper and Brothers.

Grossman, Elaine M. 2012. "Jury Out: Do Advanced Conventional Weapons Make Nuclear War More Likely?” Global Security Newswire. Aug 22. http://www.nti.org/gsn/ article/jury-out-do-advanced-conventional-weapons-makenuclear-war-more-likely/. Accessed Jul 19, 2013.

Liberman, Mark. 2004. "Empathizing with Simon BaronCohen's Cousin.” Language Log. Aug 4. http://itre.cis.upenn. edu/ myl/languagelog/archives/001311.html. Access June 20, 2013. 
Mucha, Peter. 2013. "How Boston bombs qualify as 'weapons of mass destruction'” Philly.com, Apr 25, http://articles.philly. com/2013-04-25/news/38793219_1_boston-marathon-massdestruction-weapon.

Accessed June 23, 2013.

NSC (National Security Council) 1957 Meeting. Extracted in Foreign Relations of the United States, 1955-57, 19. May 27. Washington, D.C: U.S. Government Printing Office: 499.

Nietzsche, Friedrich. 1954. The Portable Nietzsche, translated and edited Walter Kaufman. New York: Viking Press.

Oren, Ido and Ty Solomon. "Weapons of Mass Destruction: A Conceptual History." Paper for delivery at the annual meeting of the American Political Science Association, Philadelphia, Aug 31-Sep 2. 2006.

Orwell, George. 1945 [1968]. "You and the Atom Bomb" Tribune, Oct 19, reprinted in The Collected Essays, Journalism and Letters of George Orwell. ed. Sonia Orwell and Ian Angus, 4 vols. New York: Harcourt Brace Jovanovich, vol 4, 8-10.

Raskin, Marcus. (1963) “The Megadeath Intellectuals.” New York Review of Books. Nov 14: 6-7.

Reichart, John F. and W. Seth Carus. 2012. "Defining 'Weapons of Mass Destruction." Occasional Paper 8, Centre for the Study of Weapons of Mass Destruction, National Defense University. http://www.ndu.edu/press/lib/pdf/CSWMDOccasionalPapers/CSWMD_OccationalPaper-8.pdf. Accessed Jul 30, 2013.

Ritter, Scott. "Dick Cheney's Fantasy World." The Guardian. Dec 16.

Robertson, Adi. 2013. "Eric Schmidt calls for drone regulation to keep neighbours from spying on you." The Verge. Apr 13. http://www.theverge.com/2013/4/13/4220794/eric-schmidtsays-governments-must-regulate-civilian-drone-use. Accessed Jul 12, 2013.

Rothbard, Murray N. 1986. "George Orwell and the Cold War: A Reconsideration," in Robert Mulvihill, ed., Reflections on America, 1984: An Orwell Symposium. Athens and London: University of Georgia Press.
Rumsfeld, Donald. 2002. Department of Defense News Briefing. Feb 12 http://www.defense.gov/Transcripts/Transcript. aspx? TranscriptID=2636. Accessed Jul 12, 2013.

. 2002. Press Conference Transcript. NATO Headquarters, Brussels, Jun 6. http://www.nato.int/docu/speech/2002/ s020606g.htm. Accessed Jul 12, 2013.

Tannenwald, Nina. 2005. "Stigmatizing the Bomb: Origins of the Nuclear Taboo.” International Security. 29, 4, Spring: 5-49.

Thomas, Mark. 2003. "Maybe Saddam had his WMDs in a flat pack.” New Statesman 132, Jun 16: 11.

United Nations. 1946. A/Res/1(1). http://www.un.org/ga/ search/view_doc.asp?symbol=A/RES/1(I). Accessed Jun 21, 2013.

U.S. Justice Department. 2013. Criminal complaint AO 91 (Rev. 11/11) in United States of America v Dzhokhar Tsarnaev, filed April 15, 2013 in county of Suffolk, District of Massachusetts, available at http://www.justice.gov/iso/ opa/resources/363201342213441988148.pdf. Accessed June 23, 2013.

U.S. Department of Justice. 2012. Press Release. Nov. 12. http:// www.justice.gov/opa/pr/2012/November/12-nsd-1347.html. Accessed June 23, 2013.

United States of America v Eric Harroun. 2013. Affidavit. United States District Court Eastern District of Virginia, Case No. 1:13 MJ 182. Mar 28. http://www.scribd.com/ doc/132873558/Harroun-affidavit. Accessed Jul 12, 2013.

Waltz, Kenneth N.1981. "The Spread of Nuclear Weapons: More May Better.” Adelphi Papers, Number 171. London: International Institute for Strategic Studies.

Zadeh, Lotfi A. 1973. "Outline of a New Approach to the Analysis of Complex Systems and Decision Processes." IEEE Transactions on Systems, Man and Cybernetics. 3, 1: 28-44.

Žižek, Slavoj. 2005. “The Empty Wheelbarrow.” The Guardian. Feb 19. 